УдК Б24.01:51.001

DOI https://doi.org/10.32851/tnv-tech.2021.5.8

\title{
БЕРЕГОЗАХИСНА СПОРУДА
}

\author{
Мироненко I.M. - кандидат технічних наук, \\ доцент кафедри цивільної інженерії та архітектури \\ Одеського національного морського університету \\ ORCID ID: 0000-0002-5322-9859 \\ Литвиненко В.В. - старший викладач кафедри морських і річкових портів, \\ водних шляхів та їх технічної експлуатації \\ Одеського національного морського університету \\ ORCID ID: 0000-0002-0715-5190
}

Портові огороджувальні споруди: моли та хвилеломи, піддаються впливу природних явищ, щуо відбуваються у земній, водній (морській) та повітряній сферах. До дї̈ природних явищ приєднується і вплив факторів, щчо виникають внаслідок діяльності людини.

Ці фактори можуть поділятися на такі основні групи: геологічні; гідрометеорологічні; експлуатаційні; фактори виконання робіт; сейсмічні; військові.

Практика будівництва та експлуатації портових огороджувальних споруд свідчить, шо за певних випадків фактори кожної з перелічених груп можуть стати причиною деформачї споруди. Однак узагальнений аналіз матеріалів про пошкодження огороджувальних споруд дозволяє констатувати, шо в більшості випадків вирішальними для їх збереження є геологічні фактори, щуо зумовлюють характер взаємодї̈ фундаменту споруди та грунту, а також визначають стан загальної стійкості споруди і грунтового масиву, на якому вона зведена.

Портові огороджувальні споруди, піддаючись впливу досить значних вертикальних i горизонтальних сил, створюють інтенсивні та великі за площею навантаження на грунти, на яких розташовані. Високе значення напруги грунту характерне для молів $і$ хвилеломів гравітаційного типу, щзо передають навантаження на трунт безпосередньо або через підсипку. Найчастіше поверхневі шари морського дна, які є несучими для иих споруд, складаються з неоднорідних і легко стисливих грунтів. Тому геологічні фактори мають першорядне значення в проєктуванні і будівництві огороджувальних споруд. Деформаиії та аварії споруд через невідповідність проєкту або методів виробництва геологічним умовам трапляються дуже часто. Причиною такої невідповідності зазвичай є неправильне уявлення про явища, шьо відбуваються в грунті під навантаженням, а отже, застосування неправильних розрахункових схем і методів визначення взаємодії споруди $і$ грунту, що лежстьв в їі основі. Іноді ие зумовлено незадовільним проведенням геологічних вишукувань.

Ключові слова: розрідження, підводний хвилелом, піщаний грунт, динамічні дї̈, прискорення, зсуви, масиви.

\section{Mironenko I.M., Litvinenko V.V. Coastal protection structure}

Port protective structures - moles and breakwaters are exposed to natural phenomena occurring in three areas: terrestrial, water (sea) and air. The influence of factors that arise as a result of human activity is added to the action of natural phenomena.

These factors can be divided into the following main groups: geological; hydrometeorological; operational; factors of production of work; seismic; military factors.

The practice of construction and operation of port protective structures shows that, in appropriate cases, the factors of each of the listed groups can cause deformations of the structure. However, a generalized analysis of materials on damage to protective structures allows us to establish that in the overwhelming majority of cases, decisive for their safety are geological factors that determine the nature of the interaction between the foundation of a structure and the soil at its base, as well as determine the state of general stability of the structure and the soil massif on which it is erected.

Port protective structures, being exposed to very significant vertical and horizontal forces, create intense and widespread loads on the soils underlying them. The high value of soil tension is characteristic of moles and breakwaters of the gravitational type, which transfer the load to the soil directly or through the backfill. Most often, the surface layers of the seabed carrying these 
structures are composed of heterogeneous and easily compressible soils. Therefore, geological factors are of paramount importance in the design and construction of protective structures. Deformations and breakdowns of structures due to inconsistency of the design or work methods with geological conditions occur very often. The reasons for this discrepancy are usually a misconception about the phenomena occurring in the soil under load, and, as a consequence, the use of incorrect design schemes and methods for determining the interaction of the structure and the soil at its base. Sometimes this is due to unsatisfactory geological surveys.

Key words: liquefaction, underwater breakwater, sandy soil, dynamic effects, acceleration, landslides, massifs.

Берегозахисні споруди у вигляді підводних хвилеломів, хвилевідбійних стінок та бун утворюють складну систему, що включає в себе саму конструкцію і грунтове та водне середовища, що контактують 3 нею. Побудова моделей, які перебувають під впливом хвильових, інших статичних і динамічних навантажень, та їх кількісна реалізація описані в нелінійній постановці [1-2; 3, с. 87, с. 145]. Такі конструкції є дорогими і використовуються для захисту берегів від морських хвиль, для захисту берегових схилів від зсувних процесів, що виникають внаслідок розмиву грунту. Розглянемо конструкції, які забезпечують стійкість схилів до фільтраційного тиску води, тиску грунтового середовища і до навантаження, що на них діють.

Проаналізуємо одну з проблем, пов'язану з розрідженням основ під конструкціями берегових укріплень через динамічний вплив морських хвиль.

В районі Ланжерону в Одесі на відстані 100 м від берега на піщане дно було укладено паралельно береговій лінії 110 бутобетонних масивів вагою 17 тонн кожен. Довжина спорудженого хвилелому становила 250 м, ширина 2,6 м, висота - 1,47 м, а початкова глибина залягання масивів - 1,4 м нижче ординара. Після завершення будівництва північна і південна частини Ланжеронівського пляжу поповнилися піщаними наносами. Це підтвердило позитивну роль хвилелому в захисті морського узбережжя від хвильових навантажень. Згодом під динамічним впливом морських хвиль масиви хвилелому почали занурюватися в піщане дно і поступово були замиті. Однією з причин руйнування хвилелому була незадовільна підготовка основи під масиви, що була розріджена під дією хвиль.

Інші приклади руйнування споруд, пов’язані з розрідженням грунтів, наведені в роботах [4-7]. Необхідно відзначити, що це явище спостерігається і спричинює значні руйнування під час землетрусів [8].

Питаннями розрідження водонасичених піщаних грунтів стали займатися після аварії грунтової греблі у Свірстрої. Тоді ж було розпочато розробку фільтраційної теорії динамічної стійкості водонасичених пісків. Згодом фільтраційна теорія була підтверджена великою кількістю лабораторних і польових експериментів. Згідно 3 нею для визначення меж втрати стійкості водонасиченими пісками необхідно знати критичне значення інтенсивності динамічного впливу, що характеризується критичним прискоренням $\mathrm{a}_{\text {cr }}$ Поняття цього прискорення відповідає тій критичній інтенсивності коливань, коли пісок, що знаходився до цього в стабільному стані, починає знову ущільнюватися. Одеська берегова зона потребує проведення експериментів для більш точного визначення критичного прискорення пісків. Водночас можна скористатися емпіричними формулами [6-7]. Також складно обраховується розрахункове прискорення частинок у товщі водонасиченого піску $\mathrm{a}_{\text {розр }}$. Вони можуть бути визначені експериментально.

Розглянемо другий підхід, що дозволяє більш точно з'ясувати прискорення частинок. Критерієм можливості переходу піску в розріджений стан виступає нерівність фільтраційної теорії: 


$$
\mathrm{a}_{\text {розр }} \geq \mathrm{a}_{\mathrm{cr}}
$$

Проведемо дослідження підводного хвилелому, нелінійна розрахункова модель якого наведена у [2]. Вона становить систему, яка включає хвилелом, його грунтову основу і водне середовище (рис. 1).

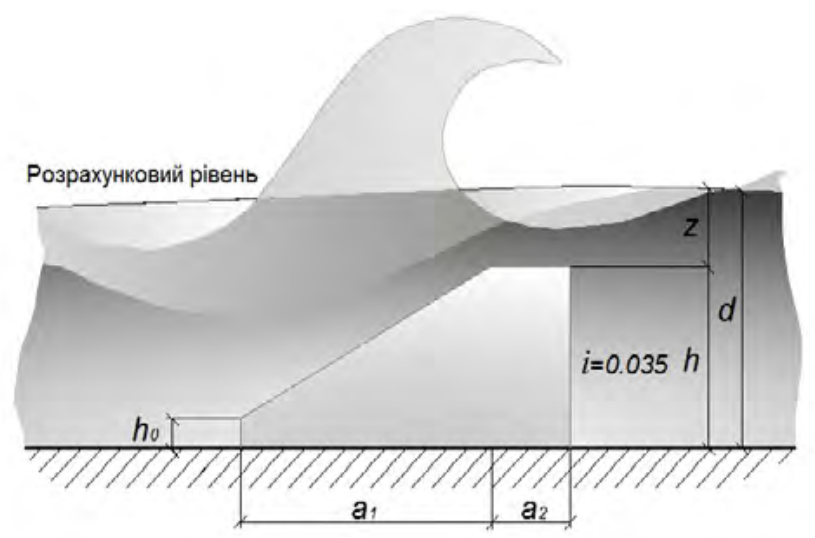

Рис. 1. Підводний хвилелом

Підводний хвилелом був випробуваний в натурних умовах в районі Одеської хвиледослідницької станції [9]. Його розміри: $\mathrm{h}_{1}=0,25 \mathrm{~m} ; \mathrm{h}=2,90 \mathrm{~m} ; \mathrm{a}_{1}=4,40 \mathrm{м}$; $\mathrm{a}_{2}=0,60$ м. Висота хвилі $\mathrm{h}_{\mathrm{s}}=3,00 \mathrm{~m}$; середня довжина $\lambda_{\text {сер }}=29$ м, а середній період $\mathrm{T}_{\text {сер }}=5$ с. Ухил дна $i=0,035$. Характеристики грунту основи: $\mathrm{E}=30 \mathrm{MПа;}$ $\mu=0,3 ; \varphi_{0}=30^{0} ; \mathrm{c}=0,003 \mathrm{MПа}$. Характеристики бетону хвилелому: $\mathrm{E}=30000 \mathrm{MПа}$; $\mu=0,2 ; \sigma_{b t}=1,3 \mathrm{MПа;} \sigma_{b}=17$ МПа. Чинне навантаження обраховується з епюри хвильового тиску за $1 \%$ забезпеченості, яка побудована за результатами натурних спостережень на Одеській хвиледослідницькій станції.

Розглянемо випадок, коли гребінь хвилі знаходиться над похилою гранню хвилелому і потім відбувається його вплив на хвилелом не у вигляді статичного навантаження, а у вигляді удару, що спостерігається за натурних умов. Для обчислення розрахункового прискорення частинок піщаної основи використовується його динамічна розрахункова модель, розроблена в [2]. Розрідження піщаного грунту визначається за фільтраційною теорією.

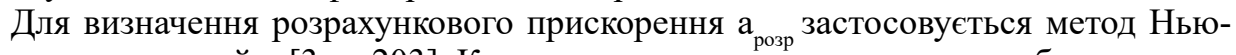
марка, викладений у [3, с. 203]. Критичне прискорення коливань а сг обчислюється за результатами віброкомпресійних випробувань. У зв'язку з відсутністю точних даних визначення $\mathrm{a}_{\mathrm{cr}}$ для намивних пісків берегової зони Одеси на підставі натурних та експериментальних даних [6-7] вважається $\mathrm{a}_{\mathrm{cr}}=5 \mathrm{~cm} / \mathrm{c}^{2}$.

Виконані розрахунки показали, що отримане розрахункове прискорення $a_{\text {розр }}$ у вузлових точках кінцевих елементів виявилося меншим за критичне прискорення $\left(0<\mathrm{a}_{\text {розр }} \leq 3 \mathrm{~cm} / \mathrm{c}^{2}\right)$, розрідження пісків не повинно відбуватися, що суперечить наведеним вище реальним прикладам. Необхідно зазначити, що:

- хвильове навантаження визначалось як усереднена величина; за натурних умов воно може відхилятись як у більший, так і в менший бік;

- як показано в роботі [10], під час удару хвилі можуть виникнути «голкові» миттєві навантаження інтенсивністю понад $5 \lambda$, де $\lambda$ - висота хвилі; час їх дії становить 0,002-0,005 с, а повторюваність не перевищує 5-8\%. 
Були виконані різні розрахунки динамічних навантажень, які показали, що в деяких вузлових точках кінцевих елементів основи виникають розрахункові прискорення, що перевищують величину критичного прискорення $\left(0<\mathrm{a}_{\text {розр }} \leq 8 \mathrm{~cm} / \mathrm{c}^{2}\right)$. Отже, в піщаній основі під хвилеломом можуть утворитися ділянки, в яких відбувається розрідження піску. Надалі ці ділянки розширюються, і масиви хвилеломів поступово занурюються в піщану основу.

Загалом для виключення розрідження основи під хвилеломом слід вживати заходи, перераховані в роботах [6-8]. В розглянутому випадку необхідно під масиви хвилелому облаштовувати кам'яну постіль. Процес розрідження і зміцнення незв'язних грунтів не залежить від їх гранулометричного складу, але зі збільшенням крупності, а отже, водонепроникності зменшується час їх перебування в розрідженому стані. В разі руйнування структури невеликих шарів великозернистих грунтів цей період такий малий, що в них практично не спостерігається прояв розрідження [11].

\section{СПИСОК ВИКОРИСТАНОЇ ЛІТЕРАТУРИ:}

1. Гришин В.А., Дорофеев В.С. Нелинейные модели конструкций, взаимодействующих с грунтовой средой. Одесса : Внешрекламсервис, 2006. 242 с.

2. Гришин В.А., Дорофеев В.С. Некоторые нелинейные модели грунтовой среды. Одесса : Внешрекламсервис, 2007. 309 с.

3. Гришин В.А., Дорофеев В.С. Расчет противооползневых сооружений. Одесса : Внешрекламсервис, 2009. 215 с.

4. Шадунц К.Ш. Оползни-потоки. Москва : Недра, 1983. 120 с.

5. Гольдин А.Л., Рассказов Л.Н. Проектирование грунтовых плотин. Москва : Энергоатомиздат, 1987. 304 с.

6. Захаров М.Н., Иващенко И.Н. К теории пластического течения грунтов. Известия Академии наук СССР. 1972. № 2. С. 185-188.

7. Малышев М.В. Прочность грунтов и устойчивость оснований сооружений. Москва : Стройиздат, 1994. 227 с.

8. Иоселевич В.А., Рассказов Л.Н., Сысоев Ю.М. Об особенностях развития поверхностей нагружения при пластическом упрочнении грунта. Известия Академии наук СССР. 1979. № 2. С. 155-161.

9. Ломизе Г.М., Крыжановский А.Л. Основные зависимости напряженного состояния и прочности песчаных грунтов. Основания, фундаменты и механика грунтов. 1966. № 3. С. 8-11.

10. Емельянова Е.П. Основные закономерности оползневого процесса. Москва : Недра, 1972. 307 с.

11. Иванов П.Л. Разжижение песчаных грунтов. Ленинград : Государственное энергетическое издание, 1962. 260 с.

\section{REFERENCES:}

1. Grishin, V.A., Dorofeev, V.S. (2006) Nelineynyie modeli konstruktsiy, vzaimodeystvuyuschih s gruntovoy sredoy [Nonlinear models of structures interacting with the ground environment]. Odesa : Vneshreklamservis. [in Ukrainian]

2. Grishin, V.A., Dorofeev, V.S. (2007) Nekotoryie nelineynyie modeli gruntovoy sredyi [Some nonlinear models of the ground environment]. Odesa : Vneshreklamservis. [in Ukrainian]

3. Grishin, V.A., Dorofeev, V.S. (2009) Raschet protivoopolznevyih sooruzheniy [Calculation of landslide protection structures]. Odesa : Vneshreklamservis. [in Ukrainian]

4. Shadunts, K.Sh. (1983) Opolzni-potoki [Landslides-streams]. Moskva : Nedra. [in Russian] 
5. Goldin, A.L., Rasskazov, L.N. (1987) Proektirovanie gruntovyih plotin [Design of soil dams]. Moskva : Energoatomizdat. [in Russian]

6. Zaharov, M.N., Ivaschenko, I.N. (1972) K teorii plasticheskogo techeniya gruntov [To the theory of plastic flow of soils]. Izvestiya Akademii Nauk SSSR. No. 2, p. 185-188. [in Russian]

7. Malyishev, M.V. (1994) Prochnost gruntov i ustoychivost osnovaniy sooruzheniy [Soil strength and stability of foundations]. Moskva : Stroyizdat. [in Russian]

8. Ioselevich, V.A., Rasskazov, L.N., Syisoev, Yu.M. (1979) Ob osobennostyah razvitiya poverhnostey nagruzheniya pri plasticheskom uprochnenii grunta [On the peculiarities of the development of loading surfaces during plastic hardening of soil]. Izvestiya Akademii Nauk. No. 2, p. 155-161. [in Russian]

9. Lomize, G.M, Kryizhanovskiy, A.L. (1966) Osnovnyie zavisimosti napryazhennogo sostoyaniya i prochnosti peschanyih gruntov [Main dependencies of the stress state and strength of sandy soils]. Osnovaniya, fundamentyi i mehanika gruntov. No. 3, pp. 8-11. [in Russian]

10. Emelyanova, E.P. (1972) Osnovnyie zakonomernosti opolznevogo protsessa [Main regularities of the landslide process]. Moskva : Nedra. [in Russian]

11. Ivanov, P.L. (1962) Razzhizhenie peschanyih gruntov [Liquefaction of sandy soils]. Leningrad : Gosudarstvennoe energeticheskoe izdanie. [in Russian] 